\title{
Forecast and Analysis of the Total Amount of Civil Buildings in China in the Future Based on Population Driven
}

\author{
Tongdan Gong ${ }^{1}$, Wenjie Zhang ${ }^{1, * \mathbb{D}}$, Jinhan Liang ${ }^{2}$, Changqing Lin ${ }^{3}$ and Kai Mao ${ }^{4}$ \\ 1 School of Energy and Power Engineering, Nanjing University of Science and Technology, \\ Nanjing 210094, China; gongtongdan@njust.edu.cn \\ 2 Norendar Internation Ltd., Shijiazhuang 050030, China; liang289922@sina.com \\ 3 Joint International Research Laboratory of Green Buildings and Built Environments, Chongqing University, \\ Chongqing 400045, China; linchq@sina.com \\ 4 Research Institute of Standards and Norms Ministry of Housing and Urban-Rural Development, \\ Beijing 100835, China; maokai@mohurd.gov.cn \\ * Correspondence: zhangwenjie@njust.edu.cn; Tel.: +86-181-1885-0609
}

Citation: Gong, T.; Zhang, W.; Liang, J.; Lin, C.; Mao, K. Forecast and Analysis of the Total Amount of Civil Buildings in China in the Future Based on Population Driven. Sustainability 2021, 13, 14051. https:// doi.org/10.3390/su132414051

Academic Editors: Shen Wei, Chen Shuqin and Wang Yaran

Received: 4 October 2021

Accepted: 8 December 2021

Published: 20 December 2021

Publisher's Note: MDPI stays neutral with regard to jurisdictional claims in published maps and institutional affiliations.

Copyright: (c) 2021 by the authors Licensee MDPI, Basel, Switzerland. This article is an open access article distributed under the terms and conditions of the Creative Commons Attribution (CC BY) license (https:// creativecommons.org/licenses/by/ $4.0 /)$.

\begin{abstract}
Controlling the scale of civil buildings is of great significance for energy saving and emission reduction in the construction field. This paper analyzes and extracts the key index parameters for the calculation of various civil building areas, establishes a detailed calculation model of the total civil building area, and constructs three different scenarios to predict various civil building areas in China from 2020 to 2060. Under the three scenarios, the total amount of civil buildings in China will reach a peak of $93.5,84.6$, and 76.3 billion $\mathrm{m}^{2}$ in 2040, 2035, and 2035, respectively. Under the constraints of energy consumption and carbon emission, this paper suggests that civil buildings develop according to the medium control scenario. In 2035, the urban per capita residential area will reach a peak of $42 \mathrm{~m}^{2}$, the urban residential area will reach 43 billion $\mathrm{m}^{2}$, the rural per capita residential area will reach the peak of $55 \mathrm{~m}^{2}$, the rural residential area will reach 20.6 billion $\mathrm{m}^{2}$, and the public building area will reach 21 billion $\mathrm{m}^{2}$. By 2060, the total area of civil buildings will drop to 76.5 billion $\mathrm{m}^{2}$, including 37.1 billion $\mathrm{m}^{2}$ of urban residential buildings, 18.5 billion $\mathrm{m}^{2}$ of rural residential buildings, and 20.9 billion $\mathrm{m}^{2}$ of public buildings.
\end{abstract}

Keywords: residential building; public building; scenario assumptions; total control; implementation path

\section{Introduction}

In September 2020, China announced the goal of "striving to peak carbon dioxide emissions by 2030 and striving to achieve carbon neutrality by 2060" [1]. Building energy efficiency is considered to be one of the key areas in China for achieving this goal. Building area data are the basis of building energy conservation. Whether calculating the total building energy consumption, analyzing energy-saving potential. and formulating energysaving objectives, it must be based on building area data.

According to the functional characteristics of civil buildings in China, it is divided into residential buildings and public buildings for statistical analysis. As shown in Table 1, some studies have estimated the stock of civil buildings in China by using corresponding methods and predicting the future. However, due to the management mode of "live only, don't care about death" (only counting the amount of new construction over the years and not counting the corresponding amount of demolition) in China's construction field, this mode brings the problem of "unclear family background" that cannot be directly provided by statistical data for the current inventory of all kinds of construction [2].

In residential buildings, the data released by the National Bureau of statistics are the results of a sample survey of residential building area and the per capita residential area converted from registered residence population [14,15]. Both Building Energy 
Conservation Association [16] and the Building Energy Conservation Research Center of Tsinghua University [17] used relevant data in the statistical yearbook to calculate the residential building area by using the methods of "fuzzy neural network" and "existing + new construction-demolition," respectively. The corresponding per capita residential building area can be converted according to the number of urban and rural permanent residents. There are three main reasons for the data differences among institutions. The first is the data source. Due to the lack of national housing census data, the per capita area data of each agency is mostly the result of sampling surveys or by using different methods based on historical data. The second is the statistical caliber of the population. The number of permanent residents and registered population also causes large differences in per capita area. The third is relative to the scope of residential area. The three concepts of building area, usable area, and usable area are quite different.

Table 1. Forecast methods and models for total amount of civil buildings.

\begin{tabular}{|c|c|c|c|c|c|}
\hline & Representative Literature & Model/Method & Application & Characteristic & Country \\
\hline 1 & $\begin{array}{l}\text { Yue Kou, } 2016 \text { [3] } \\
\text { Yong Wu, } 2017 \text { [4] } \\
\text { RISN, 2016 [2] }\end{array}$ & $\begin{array}{l}\text { Population } \times \text { per } \\
\text { capita area }\end{array}$ & $\begin{array}{l}\text { Research on total building } \\
\text { energy consumption } \\
\text { control strategy. } \\
\text { Estimation of total energy } \\
\text { consumption of residential } \\
\text { buildings in local areas }\end{array}$ & $\begin{array}{l}\text { Mathematical } \\
\text { relationship is simple } \\
\text { and intuitive. } \\
\text { Applicable to macro }\end{array}$ & China \\
\hline 2 & $\begin{array}{l}\text { Igor Sartori, } 2016 \text { [5] } \\
\text { Chen Peng, } 2015 \text { [6] } \\
\text { Veit Bürger, } 2018 \text { [7] }\end{array}$ & $\begin{array}{l}\text { Dynamic material flow } \\
\text { analysis model and } \\
\text { building inventory model } \\
\text { based on existing, new, } \\
\text { and demolition data }\end{array}$ & $\begin{array}{c}\text { Urban development } \\
\text { process. Construction } \\
\text { volume changes year by } \\
\text { year }\end{array}$ & $\begin{array}{l}\text { Applicable to } \\
\text { year-on-year } \\
\text { development } \\
\text { calculations, with higher } \\
\text { requirements for } \\
\text { historical data }\end{array}$ & $\begin{array}{l}\text { Norway } \\
\text { China } \\
\text { Germany }\end{array}$ \\
\hline 3 & Feng Qi, 2018 [8] & GIS technology & $\begin{array}{l}\text { Forecast of total building } \\
\text { energy consumption and } \\
\text { total carbon emissions }\end{array}$ & $\begin{array}{l}\text { Related to parameters } \\
\text { such as built-up area } \\
\text { and floor area ratio }\end{array}$ & China \\
\hline 4 & $\begin{array}{l}\text { Daniel B. Müller, } 2006 \text { [9] } \\
\text { André Stephan, } 2017 \text { [10] } \\
\text { CQU, 2019 [11] }\end{array}$ & $\begin{array}{l}\text { Material conservation of } \\
\text { industrial products MFA } \\
\text { (Material flow analysis) }\end{array}$ & $\begin{array}{l}\text { Research on the entire life } \\
\text { cycle of building carbon } \\
\text { emissions. Research on } \\
\text { various economic } \\
\text { indicators }\end{array}$ & $\begin{array}{c}\text { Based on the } \\
\text { conservation of } \\
\text { domestic cement, steel, } \\
\text { glass, and other building } \\
\text { materials output } \\
\text { materials }\end{array}$ & $\begin{array}{l}\text { Norway } \\
\text { USA } \\
\text { China }\end{array}$ \\
\hline 5 & $\begin{array}{c}\text { Wei Na, } 2017 \text { [12] } \\
\text { Jing Hou, } 2017 \text { [13] }\end{array}$ & $\begin{array}{l}\text { Taylor series artificial } \\
\text { neural network, linear } \\
\text { regression and other } \\
\text { specific mathemati- } \\
\text { cal models }\end{array}$ & $\begin{array}{l}\text { According to the statistical } \\
\text { yearbook data, use Taylor } \\
\text { function and fitting } \\
\text { equation to split and } \\
\text { calculate the building area }\end{array}$ & $\begin{array}{l}\text { Based on mathematical } \\
\text { statistical analysis }\end{array}$ & China \\
\hline
\end{tabular}

In terms of public building area, especially relevant data of subdividing public building types, there is an obvious gap. With the development of the social economy, the proportion of the tertiary industry in the national economy has gradually increased, and related energy consumption is mainly generated in public buildings. Energy consumption of public buildings in developed countries accounts for about $15 \%$ of total social terminal energy consumption. There are relatively many types of energy-consuming equipment in public buildings, and the system is relatively complex, which is considered to have great potential for energy saving and emission reduction [18]. At the same time, in the context of the total amount control, it is necessary to master the area of various large-scale public buildings to implement China's construction carbon trading, determine key energy consuming buildings, and allocate construction carbon quotas. Therefore, a more accurate estimation of the current stock of various public buildings in China and the prediction of 
future development are of great significance to research and decision making of related issues at the national macro level.

Currently, different institutions or scholars have different estimates of public building areas $[4,6,12,13]$. The stock data on public building area in recent years are distributed between 7 and 12 billion $\mathrm{m}^{2}$. There are two reasons for the difference in the calculation data. One is the definition of the area of public buildings. Different agencies have different choices when dividing the total amount of "urban public building," "village public building," and "industrial building." The second is the choice of measurement methods. Different methods inevitably result in data differences. The above research methods have certain reference value for the calculation of building area, but there are many types of public buildings. From the perspective of energy saving and emission reduction, the energy consumption of different types of public buildings varies greatly. The classification of public buildings facilitates follow-up research.

Mastering the detailed data of various building areas and predicting the future trend not only help in supporting the judgments of the future trends of the construction industry and upstream and downstream related industries but also provide support for the calculation of building energy consumption and carbon emission, help government departments make macro-control, promote the transformation of the construction industry, achieve the goal of energy conservation and emission reduction, and promote the high-quality development of cities.

This article analyzes and refines the key index parameters for the calculation of various civil building area, establish the corresponding calculation method for the total amount of civil buildings, including residential buildings and public buildings, and discuss energy consumption by setting three control scenarios: benchmark, medium, and strict. Based on the control objectives of the total amount of civil buildings in China under the constraints of carbon emissions, the total control objectives and development routes of various types of civil buildings in different development stages based on multi-influencing factors are provided.

\section{Classification Calculation Method of Building Area}

Residential buildings can be divided into two types: urban residences and rural residences according to their geographical distribution and living habits. Public buildings refer to buildings for people to carry out various public activities. Based on the consideration of building energy consumption and the number of buildings, combined with various public building index data in China Statistical Yearbook and Veit Bürger's classification method of public buildings [7], this paper divides public buildings into three categories from the calculation method. The first includes basic service public buildings based on administrative intervention: medical treatment, party and government office, education, culture, and transportation. The second includes commercial public buildings based on market demand: commercial office buildings and commercial buildings (accommodation, catering, wholesale, and retail). The third includes other public buildings that are inconvenient for statistics.

In order to study the total amount of civil buildings, the influencing factors of various civil buildings are identified. Currently, many scholars at home and abroad [19-24] have studied the influencing factors of building area and found that the research on the impact of population, land, resources, and economy on urban development is the most mature in terms of the demand for urban development and construction land. Among them, the comprehensive coordination of regional population, resources, environment, and economic development is an effective method for promoting regional sustainable development. Therefore, this paper extracts the micro-influencing factors such as per capita area and vacancy rate and the macro influencing factors such as society, economy, environment, and policy; analyzes the correlation of various categories of influencing factors; and determines the key influencing factors of residential buildings and public buildings, respectively. 


\subsection{Residential Building}

The total residential building area is mainly related to the per capita residential area and the number of permanent residents. The per capita residential area is mainly constrained by per capita GDP, resident income, number of households, and land resources.

\subsubsection{Per Capita GDP}

Foreign housing development experience shows that with the process of urbanization, the demand for per capita residential area is gradually increasing. The per capita residential building area in all regions of the world is related to the degree of development. It is about $54 \mathrm{~m}^{2}$ in OECD member countries (about $45 \mathrm{~m}^{2}$ in Europe and Central Asia on average), about $30 \mathrm{~m}^{2}$ in Asia (except the Middle East), and about $20 \mathrm{~m}^{2}$ in sub Saharan Africa [25]. According to the database of Eurostat [26], International Energy Agency [27], and Japan's Ministry of Land, Infrastructure, Transport and Tourism [28], when the per capita GDP (PPP) of medium-developed countries is between 20,000 and 40,000 US dollars, the per capita residential building area is $32 \sim 45 \mathrm{~m}^{2}$.

\subsubsection{Resident Income}

With the development of social economy, the increase in residents' income makes the housing demand rise gradually. Combined with the questionnaire survey on the annual income and housing area of Chinese residents conducted by Chinese General Social Survey (CGSS) [29], it was found that the overall housing construction area increases with the increase in annual income. When the annual income of residents reaches 180,000 yuan (the corresponding per capita GDP is about 40,000 US dollars), the building area of family housing is about $130 \mathrm{~m}^{2}$.

\subsubsection{Number of Households}

The number of households has a significant impact on the housing demand of Chinese residents, and the analysis of housing demand by the number of households is significantly better than the total population indicator [30]. With the development of social economy and the decline of birth rate, the average size of family households began to shrink and tended to simplify. In 2015, the average size of urban households was 2.84 persons, and households with two and three persons accounted for $21.9 \%$ and $31.7 \%$ of the total surveyed households, respectively [31]. Based on this, it was calculated that when the income of residents increases to a certain level, the expected value of the future per capita residential area that meets the needs of the family should be around $45 \mathrm{~m}^{2}$.

\subsubsection{Land Resources}

Under the constraints of land resources, the per capita residential area in cities and towns can be calculated based on the area and proportion of urban residential land and the number of populations, combined with the housing plot ratio. The specific calculation method is shown in Equations (1) and (2):

$$
\begin{gathered}
A_{p r t}=A \cdot \rho_{r e} \cdot \rho_{r e, 1} \cdot \theta \div P_{t} \\
P_{t}=r \times P
\end{gathered}
$$

where $A$ is the urban space control index, $10^{2}$ million $\mathrm{m}^{2} ; \rho_{r e}$ is the proportion of residential land; $\rho_{r e, 1}$ is the proportion of residential land in residential land; $\theta$ is the plot ratio of urban residential land; and $P_{t}$ is the resident population of cities and towns.

Compared with urban residential areas, the restriction of rural residential area is relatively loose. According to the "Law of the People's Republic of China on Land Administration," with the implementation of the rural "one household, one house" system, local village committees uniformly determine the homestead area standard of the village according to planning and actual land use. 


\subsection{Public Building}

Based on the current situation investigation and the collected existing data, the calculation methods of various public building areas and the indicators to be predicted are analyzed and refined, as shown in Figure 1.

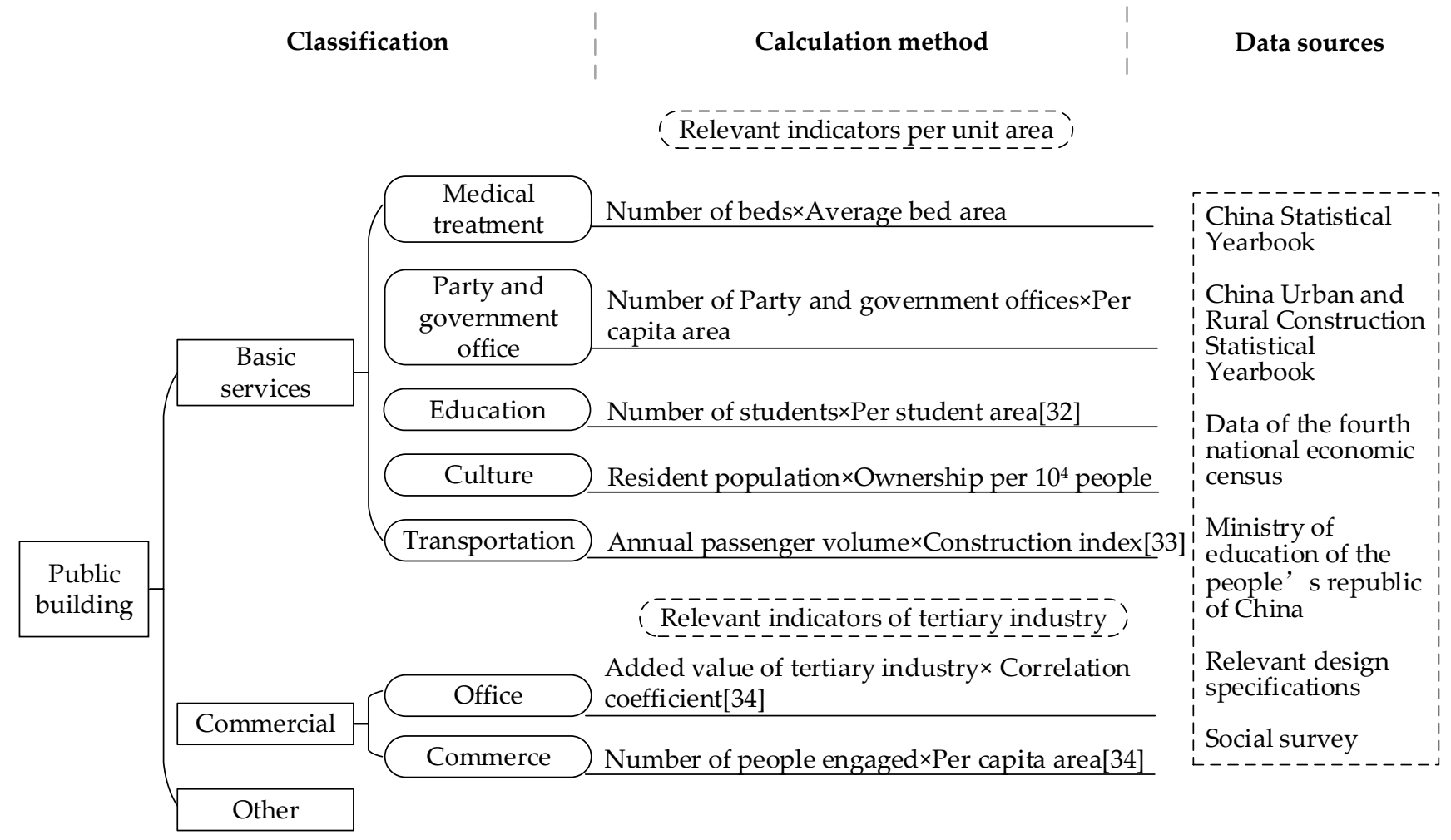

Figure 1. Calculation method of public building area [32-34].

2.2.1. Basic Service Public Buildings

Medical Building

Medical buildings mainly include hospitals, primary medical and health institutions, and professional public health institutions. The construction scale of the hospital is divided into six levels according to the number of beds. The building area of the hospital can be determined according to the average bed area and the number of beds [35]. For small medical institutions such as clinics and health centers, considering that they do not contain beds, the total amount of medical buildings can be revised according to the values in the corresponding construction specifications when calculating the total amount of medical buildings [36-39]. The relationship between the total number of existing medical buildings and the number of beds is shown in Figure 2a.

Party and Government Office

The area of the party and government office building is mainly composed of five parts: office, service room, equipment room, basic office room, and auxiliary room [40]. The total building area of office buildings for party and government agencies can be calculated according to Formula (3):

$$
S_{2}=[A+B+(A+B) \times 9 \%] / K+C
$$

where $S_{2}$ is the total building area; $A$ is the total usable area of staff offices at all levels; $B$ is the total usable area of service rooms; $9 \%$ is the area coefficient of the equipment room; $K$ is the total use area coefficient of basic office buildings; and $C$ is the total building area of ancillary buildings. 


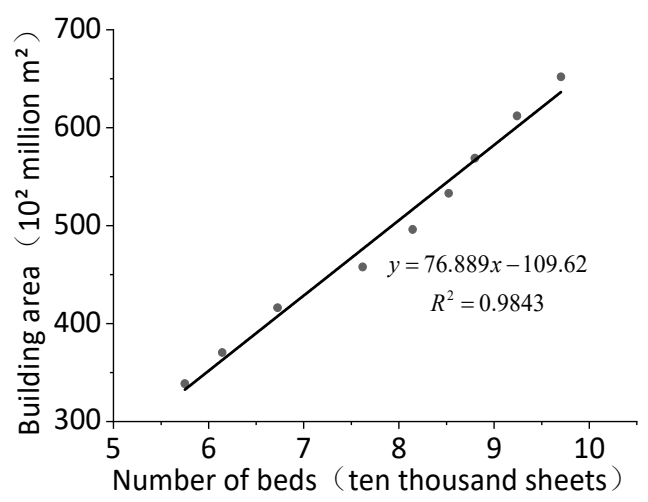

(a)

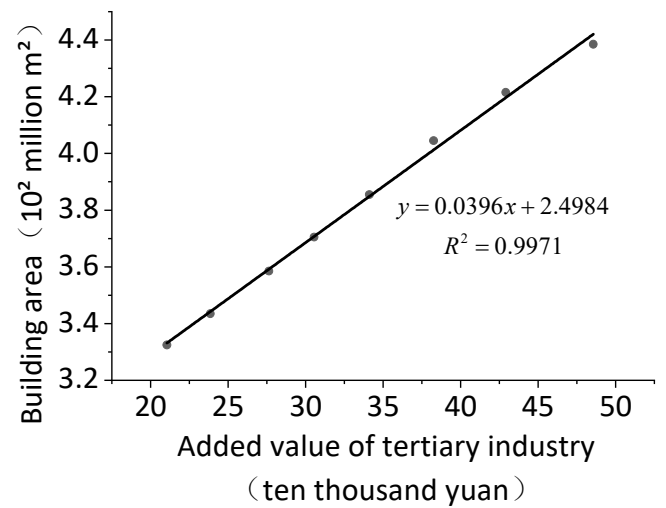

(c)

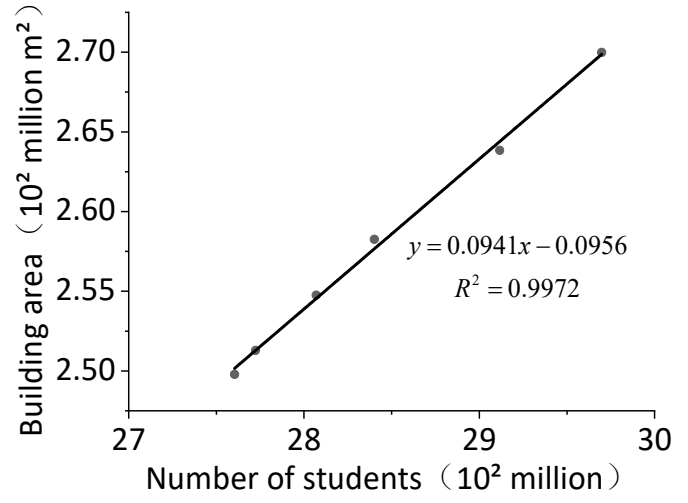

(b)

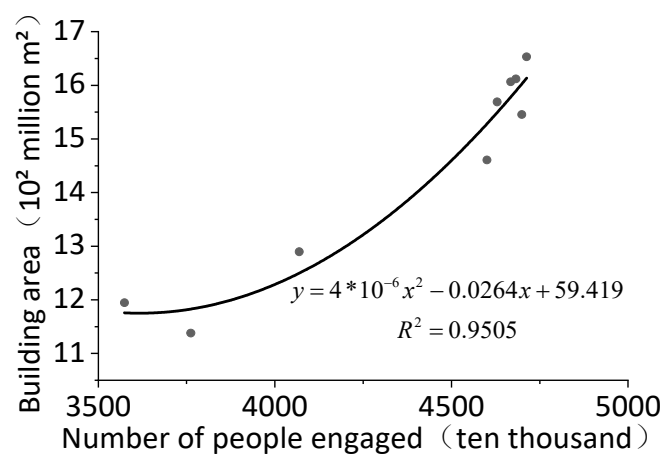

(d)

Figure 2. Fitting relationship between total amount of some public buildings and indicators. (a) The relationship between building area and number of beds; (b) The relationship between building area and the number of students; (c) The relationship between building area and the added value of tertiary industry; (d) The relationship between building area and number of people engaged.

In 2018, the number of Party and government offices in China was about 90 million. According to the population proportion of all management levels of Party and government organs in China, it can be calculated that the current per capita office area of Party and government is about $31 \mathrm{~m}^{2}$ (except for ancillary buildings). This article will use the method of the number of party and government offices and the area per capita to calculate the total number of party and government office buildings.

\section{Educational Building}

Educational buildings are divided into ten categories: ordinary colleges and universities (postgraduates), scientific research institutions, ordinary colleges and universities (junior colleges), adult higher education (junior colleges), ordinary high schools, secondary vocational schools, junior middle schools, primary schools, special education schools, and preschool education schools. According to the per-student area in various educational building construction codes [41-46] and the number of students at all levels announced by the Ministry of Education, the total educational building area in China over the years can be calculated. It can be observed from Figure $2 b$ that the educational building area is linearly related to the number of students in school, and the slope average student area is about $11 \mathrm{~m}^{2} /$ person. This paper uses the number of students and the average area of students to calculate the total amount of educational buildings.

\section{Cultural Building}

Cultural buildings generally correspond to the size of the local population. The cultural buildings calculated in this paper are mainly divided into four categories: museums, 
public libraries, art performance halls, and cultural halls. Among them, the collection area of the museum is related to the number of cultural relics in the collection [47]. The basic basis is the scale of public libraries and the number of service populations, the corresponding per capita collection of books, and the number of reading seats per 1000 people. The statistical yearbook uses the construction area of public libraries per 10,000 people in each province as the indicator. The scale of art performance halls and cultural centers is related to the number of permanent residents and the building area of institutions [48,49]. According to the relevant data in China Statistical Yearbook, the number of cultural buildings per 10,000 people in China can be calculated.

\section{Transportation Building}

Transportation buildings mainly include four types of bus passenger stations, port passenger stations, railway stations, and terminal buildings. When calculating the area of a passenger station, only the main public building area of various passenger stations is considered: the building area of the ticket hall, the waiting room, the area of the luggage room, etc. According to its corresponding construction standards [50-53], the usable area of the ticket office should be calculated based on the fact that each ticket window should not be less than $15 \mathrm{~m}^{2}$. The number of ticket windows should be calculated based on 1/120 of the maximum number of passengers gathered. The usable area of the waiting hall for ordinary passengers is calculated according to the maximum number of passengers gathered. The maximum number of people gathered can be "annual average daily passenger volume" multiplied by "calculation percentage (this article takes the average 10\%)." According to the annual passenger volume of various traffic buildings in the statistical yearbook and the per capita area specified in the corresponding construction standards, the total traffic building area can be calculated.

\subsubsection{Commercial Public Buildings \\ Commercial Office Building}

Due to the different economic divisions of labor in various regions, the scales of office buildings related to the tertiary industry are different. Currently, China's office market is dominated by leasing. By estimating the retention of office buildings before the purchase restriction order and combined with the rental area of office buildings in the market over the years, we can calculate the stock of office buildings over the years $[54,55]$. Research shows that the added value of the tertiary industry has a great impact on the office building market [56]. According to the added value of the tertiary industry in the statistical yearbook, it was found that the added value of the tertiary industry is linearly related to the area of office buildings, as shown in Figure 2c. The total amount of office buildings can be calculated by multiplying the added value of the tertiary industry by the corresponding coefficient.

\section{Commercial Buildings}

The commercial buildings counted in this paper mainly include accommodation, catering, wholesale, and retail buildings. From China Statistical Yearbook, we can obtain the number of employees and construction area of accommodation, catering, and retail industries above the quota over the years so as to calculate the change trend of per capita building area. The per capita building area of the wholesale industry can be estimated according to the building code [57]. For commercial buildings below the quota that have not been counted, the number of employees in various industries in the fourth national economic census can be used for correction. It can be observed from Figure $2 \mathrm{~d}$ that there is a certain fitting relationship between China's commercial building area and the employed population. In this paper, the per capita building area and the employed population of each industry can be used to calculate the total amount of commercial buildings. 


\subsubsection{Other Public Buildings}

In addition to the above six types of typical public buildings, there are also some public buildings that are inconvenient to count, such as gardens, communications, religion, etc. According to the results of the general survey of large public buildings in Beijing [58], the total amount of 11 types of public buildings in 2005 was about 34 million $\mathrm{m}^{2}$. According to the data in China Statistical Yearbook [59], the total amount of public buildings in Beijing in the same year is 46.8 million $\mathrm{m}^{2}$; thus, other types of public buildings not counted in Beijing account for about $25 \%$ of the total. Although the classification method of public buildings in this article is slightly different from that of the scholar, the categories of public buildings are the same; thus, this article refers to this ratio to estimate other types of public buildings.

The calculation method is shown in Equations (4)-(6):

$$
\begin{gathered}
S=S_{r}+S_{p} \\
S_{r}=A_{p r t} \times r \times P+A_{p r e} \times(1-r) \times P \\
S_{p}=S_{p j}+S_{p s}+S_{p q}
\end{gathered}
$$

where $S$ is the total area of civil buildings, $10^{2}$ million $\mathrm{m}^{2} ; S_{r}$ is the total residential building area, $10^{2}$ million $\mathrm{m}^{2} ; S_{p}$ is the total public building area, $10^{2}$ million $\mathrm{m}^{2} ; A_{p r t}$ is the per capita building area of urban residential buildings, $\mathrm{m}^{2} /$ person; $r$ is the urbanization rate, \%; $P$ is the number of permanent residents, $10^{2}$ million people; $A_{p r c}$ is the per capita building area of rural residential, $\mathrm{m}^{2}$ /person; $S_{p j}$ is the total area of basic service public buildings, $10^{2}$ million $\mathrm{m}^{2} ; S_{p s}$ is the total area of commercial public buildings, $10^{2}$ million $\mathrm{m}^{2}$; and $S_{p q}$ is the total area of other public buildings, $10^{2}$ million $\mathrm{m}^{2}$.

\subsection{Comparison and Verification of Total Civil Building Calculations}

Compared with the data of 2018, the civil building area in China is 64.8 billion $\mathrm{m}^{2}$ calculated according to the above method. According to the collected relevant data, set 2010 as the first year for prediction and then compare the historical relevant data in the statistical yearbooks from 2010 to 2018 with the model prediction results in order to verify the accuracy of the model. This paper selects the following four evaluation indicators:

(1) Root mean square error (RMSE)

$$
R M S E=\sqrt{\frac{1}{n} \sum_{i=1}^{n}\left(C_{i}-E_{i}\right)^{2}}
$$

(2) Mean absolute error $(M A E)$

$$
M A E=\frac{1}{n} \sum_{i=1}^{n}\left|C_{i}-E_{i}\right|
$$

(3) Mean relative error $(M R E)$

$$
M R E=\frac{1}{n} \sum_{i=1}^{n}\left|\frac{C_{i}-E_{i}}{E_{i}}\right|
$$

(4) Proportional absolute error $(P A E)$

$$
P A E=1-\frac{M A E}{\bar{E}}
$$

where $C_{i}$ is the model calculation value, $E_{i}$ is the statistical yearbook value, and $\bar{E}$ is the statistical yearbook average value. 
Among the above four evaluation indexes, RMSE, MAE, and MRE all represent the degree of dispersion between simulated and experimental values. The smaller the two evaluation values are, the closer the simulated value is to the experimental value, and the more accurate the calculation model is. PAE indicates the correctness and consistency of the simulated values compared with experimental values. The closer $P A E$ is to 1 , the more accurate the corresponding model is. The comparison and error analysis of various civil building area data calculated by the model from 2010 to 2018 are shown in Figure 3. By using error analysis, compared with the data in the statistical yearbook, the calculation results of this study are RMSE of 1.983 billion $\mathrm{m}^{2}, M A E$ of 1.771 billion $\mathrm{m}^{2}, M R E$ of $3.14 \%$, and $P A E$ of 0.97 . It shows that the calculation result of the model is reliable.

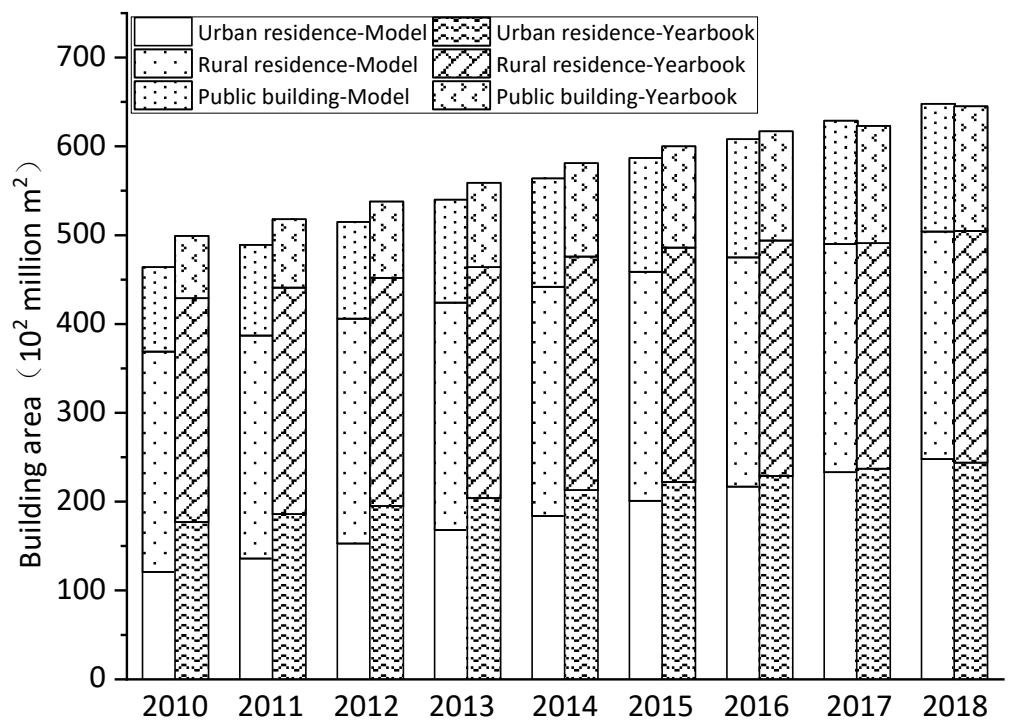

Figure 3. Comparison of building area data from 2010 to 2018.

\section{Area Forecast}

In terms of correlation, factors such as population, urbanization rate, gross domestic product (GDP), industrial structure, and construction stock are significantly related to the future construction area. In the process of establishing the prediction model, considering the parameter index changes of the above relevant influencing factors, a parametric scenario is established, which is divided into three scenarios: benchmark scenario, medium control, and strict control to predict various building areas.

\subsection{Scenario Construction}

\subsubsection{Macro Index Forecast}

Population and Urbanization Rate

Firstly, establish corresponding sub-scenarios for the relevant factors involved. The macro influencing factors considered in this study are mainly population. In 2020, China's population will only reach 1.4 billion. At present, the fertility rate is relatively low, and China has entered an era of negative population growth [60]. Negative population growth is directly affected by fertility, death, and age structure. Aiming at the problem of negative population growth in China, Zhang Xianling [61] and others predicted the future population development trend of China under different fertility levels. In this paper, the predicted results under the scenario of 1.6 fertility rate is used as the future population data for calculation. The negative population growth reaches 1.41 billion in 2027 and 1.31 billion in 2050.

International experience shows that rapid economic growth is accompanied by the rapid promotion of urbanization, and the urbanization process slows down gradually after the economic growth rate decreases. The "saturation value" of urbanization rate in different countries is significantly different. According to "Development Research Center 
Of the State Council," when the per capita GDP is USD $\$ 10,000 \sim \$ 20,000$, the urbanization rate is about 65 75\%. From 2014 to 2020, China's urbanization rate maintained an average annual growth rate of about 1 percentage point, and by 2020, the urbanization rate of permanent residents exceeded 60\% [62]. China Statistical Yearbook shows that, in 2019, the urbanization rate of China's permanent population has reached $60.6 \%$, and the per capita GDP is 70,892 yuan (slightly more than 10,000 US dollars). It is assumed that China's urbanization rate will still maintain an annual growth of $1 \%$ in the next 10 years, reach $70 \%$ in 2030, and reach 75\% in the platform period in 2040 (with reference to the experience of international urbanization rate and in combination with the constraints of China's population age structure, Rural Cultivated Land and food production, rural labor force, and other aspects, it is assumed that the peak urbanization rate in China is $75 \%$ ).

\section{Forecast of Per Capita Residential Area}

For urban residences, family housing demand, economic and social development, and land resource constraints are considered by considering that China's per capita GDP will reach moderately developed countries in the future. This paper assumes that the per capita urban residential area in China will be between 32 and $42 \mathrm{~m}^{2}$ in the future. For rural residences, considering the further urbanization development in the future, the growth rate of rural per capita residential area will be reduced. It is expected that the rural per capita residential area will reach a peak of $55 \mathrm{~m}^{2} /$ person in 2035.

\subsubsection{Forecast of Relevant Indicators of Public Buildings}

Based on historical data, referring to the development trend of developed countries and combined with China's national conditions, this paper analyzes three different scenarios of establishing benchmark, medium control, and strict control of various public building area in China in the future. For the forecast of various building area indicators, an expert survey method is adopted, and the results are shown in Table 2.

\subsection{Forecast Results}

\subsubsection{Forecast Results of Total Civil Buildings}

The prediction results of the total civil building area in China are shown in Figure 4. Under the benchmark scenario, the peak value of China's total civil buildings will reach 93.5 billion $\mathrm{m}^{2}$ in 2040. In 2035, the total amount of civil buildings will be about 92.9 billion $\mathrm{m}^{2}$. At that time, the urban per capita residential area will reach the peak of $45 \mathrm{~m}^{2}$, the urban residential area will reach 46 billion $\mathrm{m}^{2}$, the rural per capita residential area will reach $57 \mathrm{~m}^{2}$, the rural residential area will reach 21.5 billion $\mathrm{m}^{2}$, and the public building area will reach 25.4 billion $\mathrm{m}^{2}$. By 2060, the total area of civil buildings will drop to 85.5 billion $\mathrm{m}^{2}$, including 39.7 billion $\mathrm{m}^{2}$ of urban residential buildings, 20.2 billion $\mathrm{m}^{2}$ of rural residential buildings, and 25.1 billion $\mathrm{m}^{2}$ of public buildings.

Under the medium control scenario, the peak value of the total amount of civil buildings in China will be advanced in 2035, reaching 84.6 billion $\mathrm{m}^{2}$, which is 8.9 billion $\mathrm{m}^{2}$ lower than the peak value of the total amount in the benchmark scenario. In 2035 , the urban per capita residential area will reach a peak of $42 \mathrm{~m}^{2}$, the urban residential area will reach 43 billion $\mathrm{m}^{2}$, the rural per capita residential area will reach a peak of $55 \mathrm{~m}^{2}$, the rural residential area will reach 20.6 billion $\mathrm{m}^{2}$, and the public building area will reach 21 billion $\mathrm{m}^{2}$. By 2060, the total area of civil buildings will drop to 76.5 billion $\mathrm{m}^{2}$, including 37.1 billion $\mathrm{m}^{2}$ of urban residential buildings, 18.5 billion $\mathrm{m}^{2}$ of rural residential buildings, and 20.9 billion $\mathrm{m}^{2}$ of public buildings. 
Table 2. Comprehensive scenarios of various public buildings in China in the future.

\begin{tabular}{|c|c|c|c|c|c|c|}
\hline Build & ig Type & Forecast Index & Current & Benchmark Scenario & Medium Control Scenario & Strictly Control Scenario \\
\hline \multirow{8}{*}{$\begin{array}{l}\text { Basic } \\
\text { service } \\
\text { public } \\
\text { buildings }\end{array}$} & \multirow[b]{2}{*}{$\begin{array}{l}\text { Medical } \\
\text { treatment }\end{array}$} & Average bed area & $107 \mathrm{~m}^{2}$ & \multicolumn{3}{|c|}{ The average bed area increases year by year, reaching $140 \mathrm{~m}^{2}$ in 2050 and $150 \mathrm{~m}^{2}$ in 2035.} \\
\hline & & Number of beds & $\begin{array}{l}6 \text { sheets per } \\
\text { thousand people }\end{array}$ & $\begin{array}{l}\text { According to the current growth rate, } \\
\text { it will reach } 15 \text { sheets per thousand } \\
\text { people, close to the national level of } \\
\text { Japan and South Korea, and then } \\
\text { decline slowly. }\end{array}$ & $\begin{array}{l}\text { Slow growth, reaching } 9 \text { sheets per } \\
\text { thousand people in } 2035 \text {, and then } \\
\text { starting to decline. }\end{array}$ & $\begin{array}{l}\text { The number of beds has begun to } \\
\text { decline, and it will be about } 5 \text { per } \\
\text { thousand people in 2050, which is } \\
\text { close to the current level in } \\
\text { Switzerland. }\end{array}$ \\
\hline & \multirow{2}{*}{$\begin{array}{l}\text { Party and } \\
\text { government } \\
\text { office }\end{array}$} & $\begin{array}{l}\text { Number of people } \\
\text { engaged }\end{array}$ & 91 million & \multicolumn{3}{|c|}{$\begin{array}{l}\text { In } 2018 \text {, the number of party and government offices accounted for } 6.5 \% \text { of the total population, and this proportion } \\
\text { will be maintained in the future. }\end{array}$} \\
\hline & & Per capita area & $33 \mathrm{~m}^{2}$ & $\begin{array}{l}\text { According to the current growth rate, } \\
\text { it will increase to } 43.5 \mathrm{~m}^{2} \text { in } 2035 \text { and } \\
\qquad 48 \mathrm{~m}^{2} \text { in } 2050 .\end{array}$ & $\begin{array}{l}\text { Growth slows down, reaching } 39 \\
\mathrm{~m}^{2} \text { in } 2035 \text { and } 40 \mathrm{~m}^{2} \text { in } 2050 .\end{array}$ & $\begin{array}{l}\text { The per capita area has a small } \\
\text { increase, reaching } 35 \mathrm{~m}^{2} \text { in } 2050 \text {. }\end{array}$ \\
\hline & \multirow[b]{2}{*}{ Education } & Per student area & $13.5 \mathrm{~m}^{2}$ & \multicolumn{3}{|c|}{ The area per student is increasing year by year, increasing to $14.5 \mathrm{~m}^{2}$ in 2035 and $15 \mathrm{~m}^{2}$ in 2050 . } \\
\hline & & $\begin{array}{l}\text { Number of } \\
\text { students }\end{array}$ & 0.31 billion & $\begin{array}{l}\text { In } 2050 \text {, the number of students in } \\
\text { school will account for } 33 \% \text { of the } \\
\text { total population. In } 2035 \text {, the number } \\
\text { of students will reach } 0.4 \text { billion, and } \\
\text { in } 2050 \text {, there will be about } 0.42 \\
\text { billion. }\end{array}$ & $\begin{array}{l}\text { In } 2050 \text {, the number of students in } \\
\text { school will account for } 28 \% \text {. In } 2035 \text {, } \\
\text { the number of students will reach } \\
0.36 \text { billion, and in } 2050 \text {, it will be } \\
\text { about } 0.365 \text { billion. }\end{array}$ & $\begin{array}{c}\text { In } 2050 \text {, the proportion of students in } \\
\text { school will reach } 26 \% \text {. In } 2035 \text {, the } \\
\text { number of students will reach } 0.34 \\
\text { billion, and in } 2050 \text {, it will reach } 0.35 \\
\text { billion. }\end{array}$ \\
\hline & \multirow[t]{2}{*}{ Culture } & $\begin{array}{l}\text { Ownership per } \\
10,000 \text { people }\end{array}$ & $480 \mathrm{~m}^{2}$ & $\begin{array}{l}\text { Rapid growth, with an average } \\
\text { growth rate of } 2.2 \% \text { from } 2020 \text { to } 2050 . \\
\text { The amount per } 10,000 \text { people will } \\
\text { reach } 710 \mathrm{~m}^{2} \text { in } 2035 \text { and } 940 \mathrm{~m}^{2} \text { in } \\
2050 .\end{array}$ & $\begin{array}{l}\text { The average growth rate from } 2020 \\
\text { to } 2050 \text { is } 1.7 \% \text {, and the amount per } \\
10,000 \text { people will reach } 650 \mathrm{~m}^{2} \text { in } \\
2035 \text { and } 800 \mathrm{~m}^{2} \text { in } 2050 \text {. }\end{array}$ & $\begin{array}{l}\text { The growth rate has slowed down, } \\
\text { with an average growth rate of } 1.5 \% \\
\text { from } 2020 \text { to } 2050 \text {, and the amount } \\
\text { per } 10,000 \text { people will reach } 625 \mathrm{~m}^{2} \text { in } \\
2035 \text { and } 740 \mathrm{~m}^{2} \text { in } 2050 .\end{array}$ \\
\hline & & $\begin{array}{c}\text { Annual } \\
\text { automobile } \\
\text { passenger volume }\end{array}$ & 13.3 billion & $\begin{array}{l}\text { In a downward trend, the average } \\
\text { annual passenger traffic between } 2020 \\
\text { and } 2050 \text { will reach } 7.5 \text { times the total } \\
\text { population, and the annual passenger } \\
\text { traffic will reach } 7.9 \text { billion in } 2050 .\end{array}$ & $\begin{array}{l}\text { Decreasing year by year, the } \\
\text { average annual passenger traffic } \\
\text { between } 2020 \text { and } 2050 \text { will reach } \\
6.5 \text { times the total population, and } \\
\text { the annual passenger traffic will } \\
\text { reach } 6.7 \text { billion in } 2050 .\end{array}$ & $\begin{array}{l}\text { Rapid decline, the average annual } \\
\text { passenger traffic between } 2020 \text { and } \\
2050 \text { will reach } 5.5 \text { times the total } \\
\text { population, and the annual passenger } \\
\text { traffic will reach } 5.5 \text { billion in } 2050 \text {. }\end{array}$ \\
\hline
\end{tabular}


Table 2. Cont.

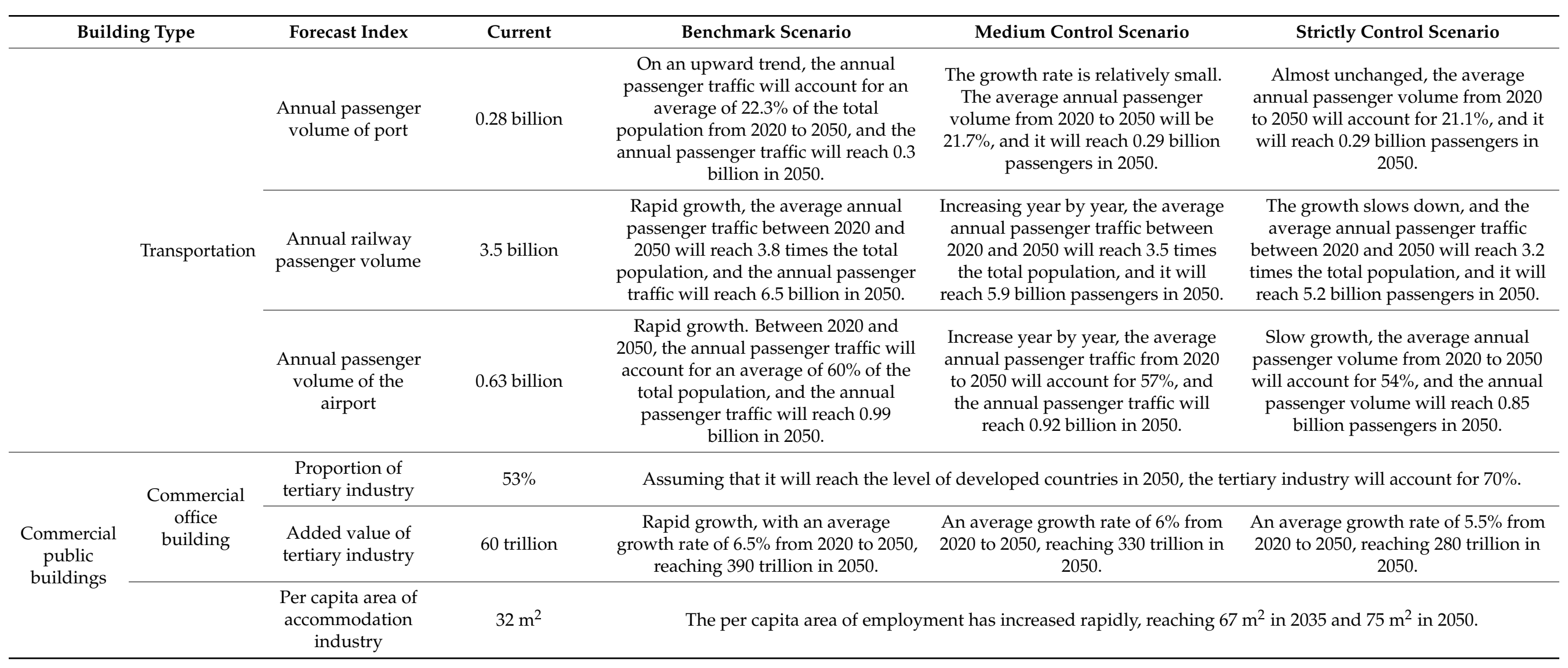


Table 2. Cont

\begin{tabular}{|c|c|c|c|c|c|}
\hline Building Type & Forecast Index & Current & Benchmark Scenario & Medium Control Scenario & Strictly Control Scenario \\
\hline \multirow{6}{*}{$\begin{array}{l}\text { Commercial } \\
\text { buildings }\end{array}$} & $\begin{array}{l}\text { Number of } \\
\text { employees in } \\
\text { accommodation } \\
\text { industry }\end{array}$ & 5.17 million & $\begin{array}{l}\text { First rise and then fall, reaching } 14.8 \\
\text { million in } 2035 \text {, and falling to } 11.15 \\
\text { million in } 2050 \text {. }\end{array}$ & $\begin{array}{l}\text { Slow growth, about } 8.9 \text { million in } \\
2050 .\end{array}$ & $\begin{array}{l}\text { The increase is small, about } 6.65 \\
\text { million in } 2050 .\end{array}$ \\
\hline & $\begin{array}{l}\text { Per capita area of } \\
\text { catering industry }\end{array}$ & $35 \mathrm{~m}^{2}$ & \multicolumn{3}{|c|}{ The per capita area of employment has increased year by year, reaching $59 \mathrm{~m}^{2}$ in 2035 and $65 \mathrm{~m}^{2}$ in 2050 . } \\
\hline & $\begin{array}{c}\text { Number of } \\
\text { employees in } \\
\text { catering industry }\end{array}$ & 6.31 million & $\begin{array}{l}\text { Rapid growth, reaching } 9.4 \text { million in } \\
2035 \text { and } 9.5 \text { million in } 2050 .\end{array}$ & $\begin{array}{l}\text { Slow growth, reaching } 6.8 \text { million in } \\
2050 .\end{array}$ & $\begin{array}{c}\text { Decrease year by year, down to } 5.9 \\
\text { million in } 2050 .\end{array}$ \\
\hline & $\begin{array}{l}\text { Per capita area of } \\
\text { wholesale } \\
\text { industry }\end{array}$ & $36 \mathrm{~m}^{2}$ & \multicolumn{3}{|c|}{ The growth rate of per capita area of employment is relatively small, reaching $39 \mathrm{~m}^{2}$ in 2035 and $40 \mathrm{~m}^{2}$ in 2050 . } \\
\hline & $\begin{array}{l}\text { Number of } \\
\text { employees in the } \\
\text { wholesale } \\
\text { industry }\end{array}$ & 21.13 million & $\begin{array}{l}\text { Rapid growth, reaching } 24.9 \text { million } \\
\text { in } 2035 \text { and } 26.35 \text { million in } 2050 .\end{array}$ & $\begin{array}{l}\text { Slow growth, reaching } 25.3 \text { million } \\
\text { in } 2050 .\end{array}$ & $\begin{array}{l}\text { The increase is small, about } 23.8 \\
\text { million in } 2050 .\end{array}$ \\
\hline & $\begin{array}{l}\text { Number of retail } \\
\text { employees }\end{array}$ & 21.03 million & $\begin{array}{l}\text { First rise and then fall, reaching } 27.2 \\
\text { million in } 2035 \text { and falling to } 26.9 \\
\text { million in } 2050 .\end{array}$ & $\begin{array}{l}\text { Almost unchanged, about } 22.4 \\
\text { million in } 2050 .\end{array}$ & $\begin{array}{l}\text { Decrease year by year, about } 19.7 \\
\text { million in } 2050 .\end{array}$ \\
\hline
\end{tabular}




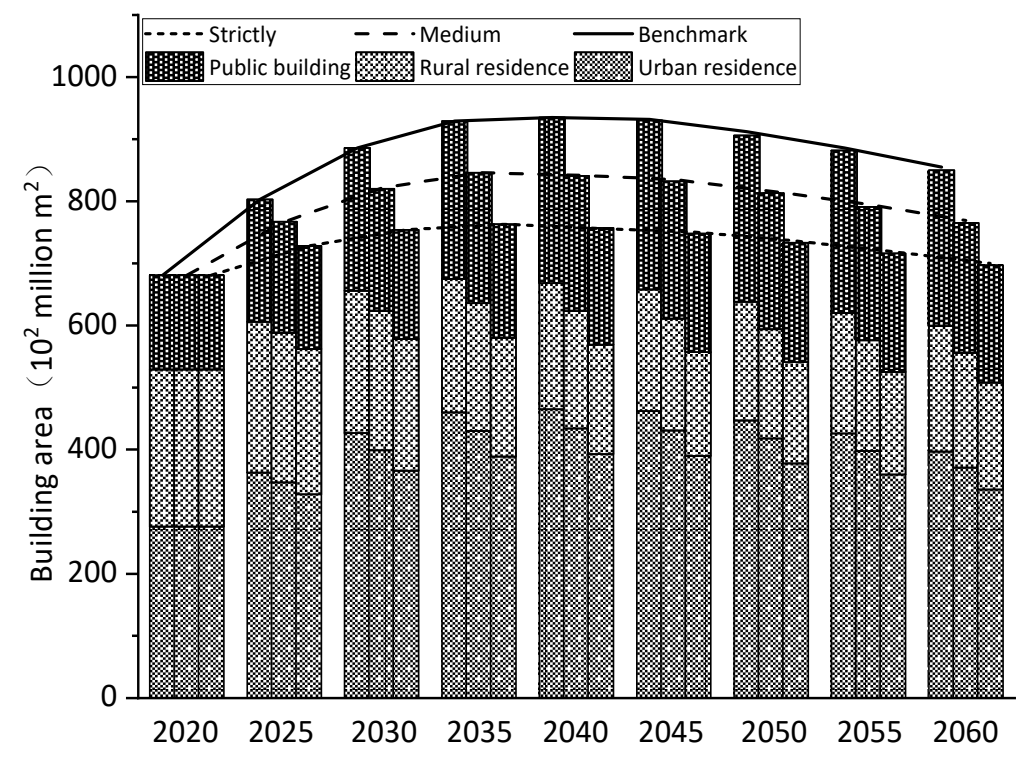

Figure 4. Forecast of total civil buildings in China in the future under different scenarios.

Under the strict control scenario, the peak value of the total amount of civil buildings in China also appears in 2035, which will be about 76.3 billion $\mathrm{m}^{2}, 17.2$ billion $\mathrm{m}^{2}$ lower than the peak value of the total amount in the benchmark scenario. In 2035, the urban per capita residential area will reach the peak of $38 \mathrm{~m}^{2}$, the urban residential area will reach 38.9 billion $\mathrm{m}^{2}$, the rural per capita residential area will reach $51 \mathrm{~m}^{2}$, the rural residential area will reach 19.1 billion $\mathrm{m}^{2}$, and the public building area will reach 18.3 billion $\mathrm{m}^{2}$. By 2060, the total area of civil buildings will drop to 70 billion $\mathrm{m}^{2}, 15.5$ billion $\mathrm{m}^{2}$ less than the benchmark scenario. At that time, the urban residential building area will reach 33.6 billion $\mathrm{m}^{2}$, the rural residential area will reach 17.2 billion $\mathrm{m}^{2}$, and the public building area will reach 18.9 billion $\mathrm{m}^{2}$.

\subsubsection{Forecast Results of Total Public Buildings}

The forecast results of total public building area in China are shown in Figure 5. It can be observed that public buildings in China are mainly medical, educational, office, and commercial buildings, accounting for about $73 \%$ of the total. The medical building area varies greatly under different scenarios. Under the benchmark scenario, it reaches a peak of 3.4 billion $\mathrm{m}^{2}$ around 2035 and drops to about 1.7 billion $\mathrm{m}^{2}$ by 2060, while it remains almost unchanged at about 1.1 billion $\mathrm{m}^{2}$ under the strict control scenario. The growth of office buildings and educational buildings is relatively stable. Under the benchmark scenario, office buildings in 2060 increased by $78 \%$ compared with 2020, while educational buildings increased by $47 \%$. Under the strict control scenario, the office buildings reached 4.5 billion $\mathrm{m}^{2}$ in 2060 , a decrease of 1.7 billion $\mathrm{m}^{2}$ compared with the benchmark scenario is observed, and the educational buildings decreased by 1.1 billion $\mathrm{m}^{2}$. The growth of commercial buildings is obvious. Under the benchmark scenario, it reached 4.5 billion $\mathrm{m}^{2}$ in 2060, which is an increase of about 77\% compared with 2020. Cultural and transportation buildings account for a relatively small proportion in public buildings. Cultural buildings are controlled at about 100 million $\mathrm{m}^{2}$ and transportation buildings are about 18 million $\mathrm{m}^{2}$, which has little impact on the development trend of the total amount of public buildings. 


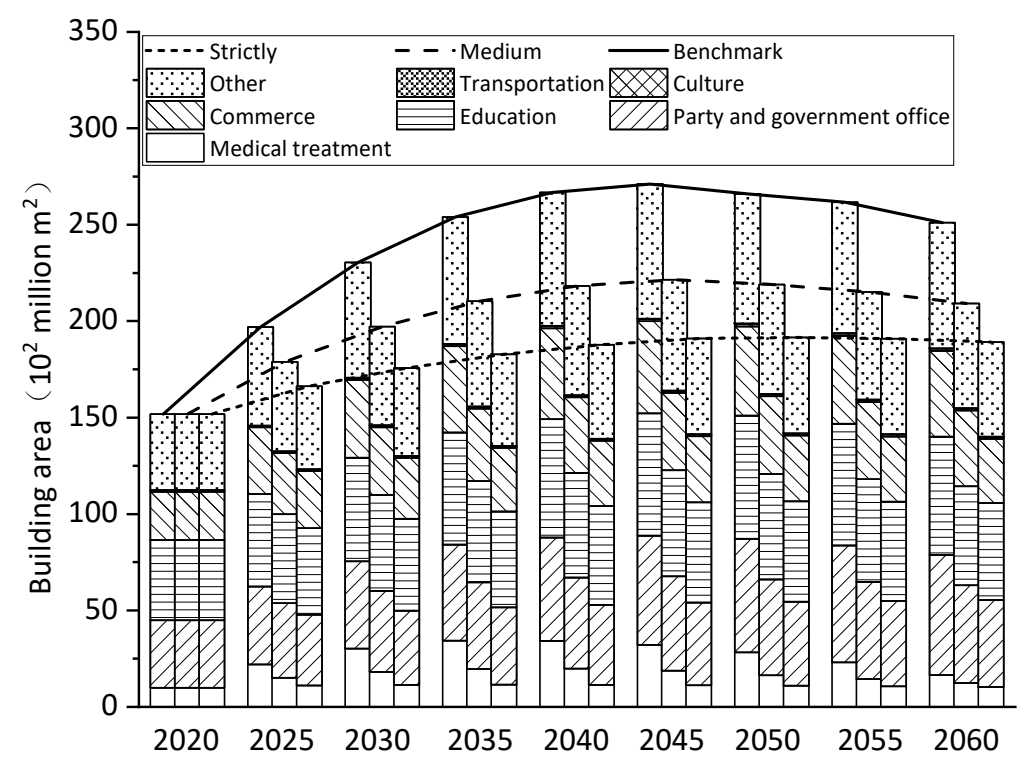

Figure 5. Forecast of total amount of various public buildings in China in the future under different scenarios.

\section{Results and Discussion}

\subsection{Analysis on the Total Amount of Civil Buildings under the Constraints of Energy Consumption and Carbon Emission}

In order to cope with climate change and achieve the goal of carbon peak, China has included the formulation of the action plan for carbon peak by 2030 as one of the important tasks in the near future. Building area is an important basis for the calculation of total building energy consumption and total carbon emission.

\subsubsection{Energy Consumption Constraint}

The Energy Research Institute, National Development and Reform Commission [63] calculated the carbon emission limit from 2005 to 2050 and the total energy consumption in key node years under different carbon emission scenarios. Under the enhanced low-carbon scenario, carbon emission will reach a peak in 2030, and the total energy consumption will be about 4.275 billion tce.

As for the proportion of building energy consumption in the total social energy consumption, currently, with the exception of the split result according to China Statistical Yearbook being slightly lower than $20 \%$, other conclusions are higher than $20 \%$, while the building energy consumption in European and American developed countries will account for $1 / 3$ of the total social energy consumption. Assuming that building energy consumption accounts for $25 \%$ of the total social energy consumption in the future, China's building energy consumption should be controlled within 1.068 billion tce in 2030 .

Refer to the setting of energy consumption intensity of various buildings in the future under the strict control scenario of the Research Institute of Standards and Norms Ministry of Housing and Urban-Rural Development (the energy consumption intensity of urban residence is about $12 \mathrm{kgce} /\left(\mathrm{m}^{2} \cdot \mathrm{a}\right)$, the energy consumption intensity of rural residence is about $9 \mathrm{kgce} /\left(\mathrm{m}^{2} \cdot \mathrm{a}\right)$, and the energy consumption intensity of public buildings is about $\left.21 \mathrm{kgce} /\left(\mathrm{m}^{2} \cdot \mathrm{a}\right)\right)$ [2]. Combined with the forecast results of the total amount of civil buildings in this paper, the total energy consumption of civil buildings under different scenarios is shown in Figure 6.

Under the three scenarios, the total building energy consumption will reach 1.16 , 1.05 , and 0.96 billion tce, respectively, in 2030. In order to achieve the goal of total energy consumption control, the building area should be controlled at least under the medium control scenario. 


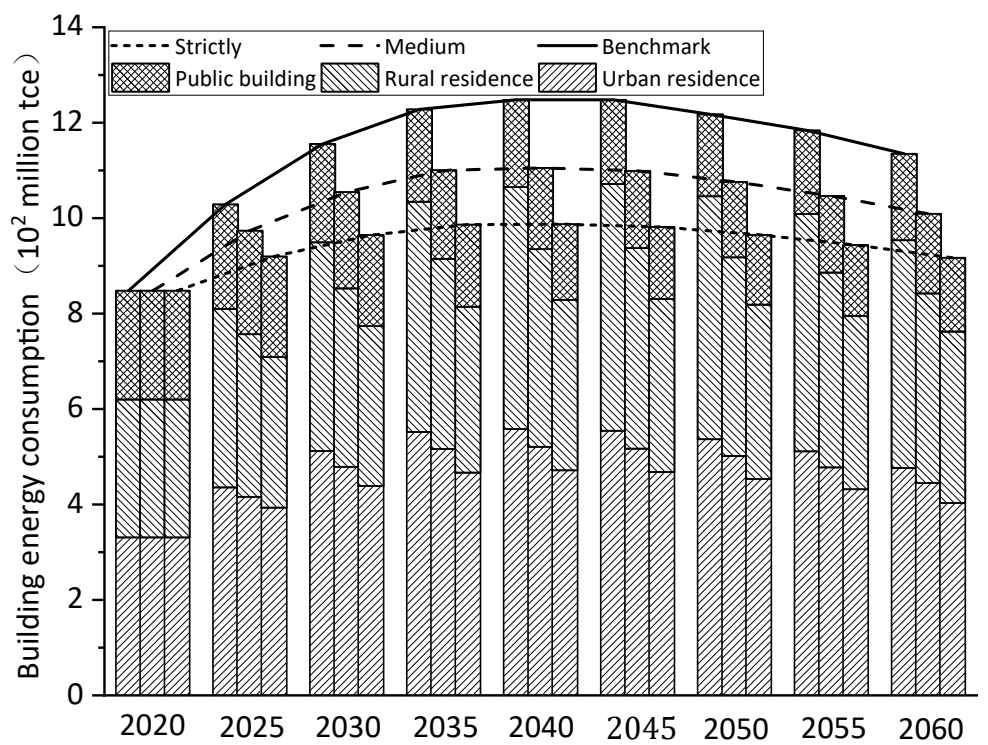

Figure 6. Comparison of total energy consumption of civil buildings in China in the future under different scenarios.

\subsubsection{Carbon Emission Constraints}

The calculation of carbon emission factor is closely related to energy structure. Referring to the forecast made by Yang et al. [64] on the change trend of China's energy structure from 2020 to 2050, taking the future carbon emission factor as $1.8 \mathrm{~kg} / \mathrm{kg}$, China's building carbon emission should be controlled within 1.924 billion $\mathrm{tCO}_{2}$ by 2030.Thus, carbon emission per unit area of various buildings in the future is obtained. The carbon emission intensity of urban residence is about $21.6 \mathrm{kgCO}_{2} /\left(\mathrm{m}^{2} \cdot \mathrm{a}\right)$, that of rural housing is about $16.2 \mathrm{kgCO}_{2} /\left(\mathrm{m}^{2} \cdot \mathrm{a}\right)$, and that of public buildings is about $34.2 \mathrm{kgCO}_{2} /\left(\mathrm{m}^{2} \cdot \mathrm{a}\right)$. Combined with the forecast results of the total amount of civil buildings in this paper, the total carbon emission of civil buildings under different scenarios is shown in Figure 7.

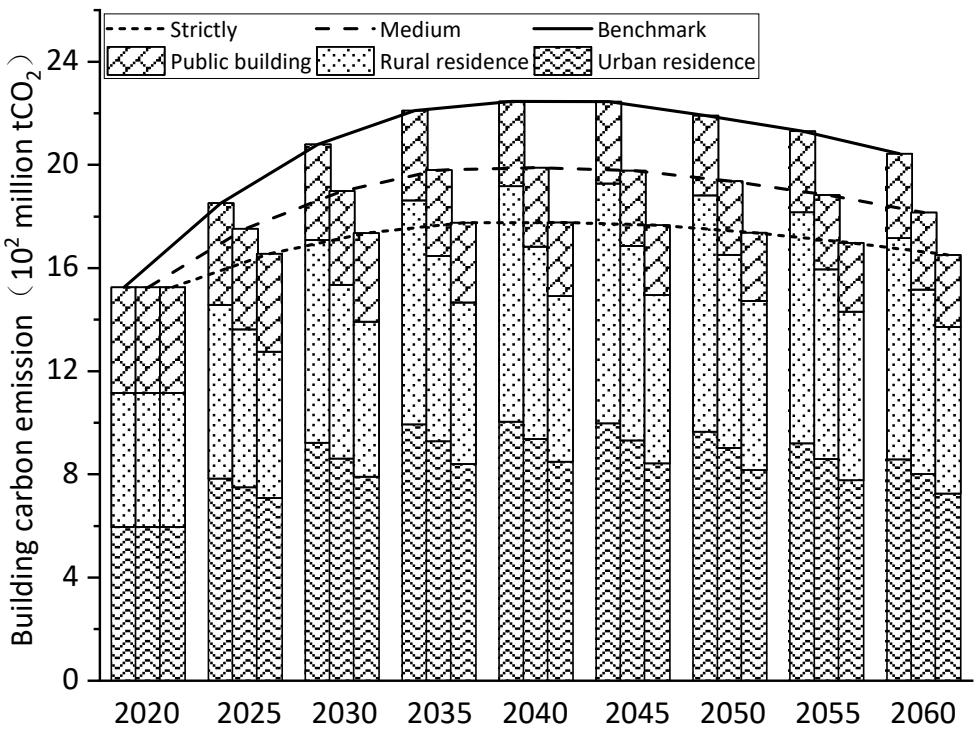

Figure 7. Comparison of total carbon emission of civil buildings in China in the future under different scenarios.

Under the three scenarios, the total building carbon emissions will reach 2.08, 1.898, and 1.736 billion $\mathrm{tCO}_{2}$, respectively, in 2030. Therefore, if we want to achieve the goal of total carbon emission control, the building area should also be controlled at least under 
the medium control scenario. Under this scenario, the civil building area will reach a peak of about 84.6 billion $\mathrm{m}^{2}$ in 2035, including 43 billion $\mathrm{m}^{2}$ of urban residential area, 20.6 billion $\mathrm{m}^{2}$ of rural residential area, and 21 billion $\mathrm{m}^{2}$ of public buildings. Subsequently, the total amount of civil buildings in China decreased slowly, reaching about 76.5 billion $\mathrm{m}^{2}$ by 2060 , including 37.1 billion $\mathrm{m}^{2}$ of urban residence, 18.5 billion $\mathrm{m}^{2}$ of rural residence, and 20.9 billion $\mathrm{m}^{2}$ of public buildings.

\subsection{Stage Objective and Implementation Route Analysis}

China is in a period of rapid urbanization. A large number of rural people have transferred to cities, and the demand for residential building and public building has increased significantly. We take stricter measures for various types of civil buildings than at present and set phased goals, respectively, for step-by-step implementation; moreover, control is needed to achieve the total amount control goal of civil building under the above medium control scenario. The specific path of total amount control of civil buildings is shown in Table 3 [65-70], and we strive to realize new urbanization and equalization of public services by 2060 .

\subsection{Discussion on Forecast Assumptions}

Under the scenario of medium area control and strict control of energy consumption intensity, considering the improvement of residents' living standards, the development of renewable energy, the technological innovation of energy consuming equipment, the improvement of efficiency, technological progress, and other factors in the future, by 2060, the energy consumption intensity of urban housing and public buildings will decrease by about $10 \%$ and that of rural housing will increase by about $10 \%$ on the basis of 2030 [2] Then, on the basis of constant total energy consumption, the total amount of civil buildings will reach 81.2 billion $\mathrm{m}^{2}$ in 2060 . Among them, urban residential buildings and public buildings reach 41.2 billion $\mathrm{m}^{2}$ and 23.2 billion $\mathrm{m}^{2}$, respectively, and the control measures that are slightly stricter than the benchmark control and slightly looser than the medium control can be adopted. The rural residential building area will decrease to 16.8 billion $\mathrm{m}^{2}$; thus, more stringent measures than strict control of the scenario need to be taken. At the same time, we should provide more prominence to promoting the use of biomass energy and developing renewable energy building applications, such as biogas, photothermal, photovoltaic power generation, solar greenhouse, etc., so as to reduce increased energy consumption due to the improvement of rural residents' living standards. 
Table 3. Phased control objectives and implementation routes of various civil buildings in China in the future.

\begin{tabular}{|c|c|c|c|c|c|}
\hline & & $2020 \sim 2025$ & $2026 \sim 2030$ & 2031 2035 & $2036 \sim 2060$ \\
\hline \multirow[b]{2}{*}{$\begin{array}{c}\text { Civil } \\
\text { building }\end{array}$} & $\begin{array}{l}\text { Control } \\
\text { objectives }\end{array}$ & $\begin{array}{l}\text { 1. The total amount is controlled at } \\
68.1 \sim 26.7 \text { billion } \mathrm{m}^{2} \text {. } \\
2 \text {. The population is cotrolled at } 1.402 \sim 1.41 \\
\text { billion. } \\
\text { 3. The average annual net increase is about } \\
2.4 \text { billion } \mathrm{m}^{2} \text { /year. }\end{array}$ & $\begin{array}{l}\text { 1. The total amount is controlled at } \\
78 \sim 82.1 \text { billion } \mathrm{m}^{2} \text {. } \\
\text { 2. The population will peak at } 1.412 \\
\text { billion in } 2027 \text { and reach } 1.408 \text { billion } \\
\text { in } 2030 \text {. } \\
\text { 3. The average annual net increase is } \\
\text { about } 1.8 \text { billion } \mathrm{m}^{2} / \text { year. }\end{array}$ & $\begin{array}{l}\text { 1. The total amount is controlled at } \\
82.8 \sim 84.6 \text { billion } \mathrm{m}^{2} \text {. } \\
\text { 2. The population is controlled at } 1.4 \\
\text { billion in } 2035 \text {. } \\
\text { 3. The average annual net increase is } \\
\text { about } 1.2 \text { billion } \mathrm{m}^{2} / \text { year, and the area } \\
\text { reaches the peak. }\end{array}$ & $\begin{array}{l}\text { 1. The total amount is controlled at } \\
84.6 \sim 76.5 \text { billion } \mathrm{m}^{2} \text {. } \\
\text { 2. The population is controlled at } \\
\text { 1.22 billion in } 2060 \text {. } \\
\text { 3. Balance between new } \\
\text { construction and demolition. }\end{array}$ \\
\hline & $\begin{array}{c}\text { Policy } \\
\text { measures }\end{array}$ & $\begin{array}{l}\text { 1. Optimize the spatial pattern of land, } \\
\text { adhere to the rigid constraint of resource } \\
\text { and environmental carrying capacity, and } \\
\text { conduct a good job in the planning of } \\
\text { construction land. } \\
\text { 2. Clarify the decomposition objectives and } \\
\text { make local building scale planning. } \\
\text { 3. Control the increment, gradually shift } \\
\text { the focus of construction from incremental } \\
\text { construction to improving quality, stock } \\
\text { transformation, and structural adjustment. }\end{array}$ & $\begin{array}{l}\text { 1. Further optimize and improve the } \\
\text { spatial pattern of the country. } \\
2 \text {. The building quality has been } \\
\text { further improved. } \\
\text { 3. All kinds of building structures are } \\
\text { reasonable, and the utilization rate and } \\
\text { service life are greatly improved. }\end{array}$ & $\begin{array}{l}\text { Basically realize a new type of } \\
\text { urbanization. }\end{array}$ & Realize a new type of urbanization. \\
\hline $\begin{array}{c}\text { Urban } \\
\text { residence }\end{array}$ & $\begin{array}{l}\text { Policy } \\
\text { measures }\end{array}$ & $\begin{array}{l}\text { 1. Control the increment, improve the } \\
\text { quality and transform the stock, and } \\
\text { improve the quality of the residence. Green } \\
\text { buildings account for } 40 \% \text { of new buildings. } \\
\text { 2. Strengthen the renovation of old } \\
\text { communities, prepare a reconstruction plan, } \\
\text { and complete the reconstruction of the } \\
\text { community built before } 2000 \text {. }\end{array}$ & $\begin{array}{l}\text { 1. Significantly improved residential } \\
\text { quality. Green buildings account for } \\
60 \% \text { of new buildings. } \\
\text { 2. Continue to carry out the renovation } \\
\text { of the old community according to the } \\
\text { plan. The reconstruction of } 150 \text { million } \\
\text { buildings in hot summer and cold } \\
\text { winter areas has been completed. }\end{array}$ & $\begin{array}{l}\text { 1.Green buildings account for } 70 \% \text { of } \\
\text { new buildings. } \\
2 \text {. The reconstruction of } 150 \text { million } \\
\text { buildings in hot summer and cold } \\
\text { winter areas has been completed. }\end{array}$ & $\begin{array}{l}\text { 1. Green buildings account for } \\
100 \% \text { of new buildings. } \\
\text { 2. The reconstruction of } 450 \text { million } \\
\text { buildings in hot summer and cold } \\
\text { winter areas has been completed. }\end{array}$ \\
\hline
\end{tabular}


Table 3. Cont.

\begin{tabular}{|c|c|c|c|c|c|}
\hline & & $2020 \sim 2025$ & $2026 \sim 2030$ & 2031 2035 & $2036 \sim 2060$ \\
\hline \multirow[b]{2}{*}{$\begin{array}{l}\text { Rural } \\
\text { residence }\end{array}$} & $\begin{array}{l}\text { Control } \\
\text { objectives }\end{array}$ & $\begin{array}{l}\text { 1. The total amount is controlled at } \\
\text { 25.3 24.1 billion } \mathrm{m}^{2} \text {. } \\
\text { 2. The per capita area is between } 47 \text { and } 51 \\
\mathrm{~m}^{2} \text {. } \\
\text { 3. The area of newly built rural houses is } \\
\text { gradually decreasing, and the amount of } \\
\text { demolition is greater than the newly added } \\
\text { amount, with a negative growth of about } \\
0.23 \text { billion } \mathrm{m}^{2} / \text { year. }\end{array}$ & $\begin{array}{l}\text { 1. The total amount is controlled at } \\
23.8 \sim 22.4 \text { billion } \mathrm{m}^{2} \text {. } \\
\text { 2. The per capita area is between } 51 \\
\text { and } 54 \mathrm{~m}^{2} \text {. } \\
\text { 3. The negative growth is maintained } \\
\text { at approximately } 0.33 \text { billion } \mathrm{m}^{2} / \text { year. }\end{array}$ & $\begin{array}{l}\text { 1. The total amount is controlled at } \\
22.1 \sim 20.6 \text { billion } \mathrm{m}^{2} \text {. } \\
2 \text {. The per capita area is between } 54 \text { and } \\
55 \mathrm{~m}^{2} \text {. } \\
\text { 3. The negative growth slows down, } \\
\text { about } 0.35 \text { billion } \mathrm{m}^{2} / \text { year. }\end{array}$ & $\begin{array}{l}\text { 1. The total amount is controlled at } \\
\text { 20.2 } 18.5 \text { billion } \mathrm{m}^{2} \text {. } \\
\text { 2. The per capita area is about } 55 \\
\mathrm{~m}^{2} \text {. } \\
\text { 3. The negative growth gradually } \\
\text { tends to balance, about } 0.17 \text { billion } \\
\mathrm{m}^{2} / \text { year, and reverse urbanization } \\
\text { may occur. }\end{array}$ \\
\hline & $\begin{array}{l}\text { Policy } \\
\text { measures }\end{array}$ & $\begin{array}{l}\text { 1. Promote the improvement of the quality } \\
\text { and efficiency of county towns, absorb the } \\
\text { migrant population from rural areas, and } \\
\text { enhance coordination between urban and } \\
\text { rural areas. } \\
\text { 2. Strengthen the planning of rural housing } \\
\text { and improve quality and use functions. } \\
\text { Pilot prefabricated rural residential } \\
\text { buildings, accounting for } 30 \% \text {. } \\
\text { 3. Green buildings account for } 30 \% \text { of new } \\
\text { rural residential buildings. }\end{array}$ & $\begin{array}{l}\text { 1. More coordination between urban } \\
\text { and rural areas. } \\
\text { 2. The planning and design of rural } \\
\text { residences are reasonable, and the } \\
\text { quality and use functions are further } \\
\text { improved. Prefabricated rural } \\
\text { residential buildings account for } 40 \% \text {. } \\
\text { 3. Green buildings account for } 40 \% \text { of } \\
\text { new rural residential buildings. }\end{array}$ & $\begin{array}{l}\text { 1. The equalization of basic public } \\
\text { services in rural areas has been basically } \\
\text { realized. } \\
\text { 2. Large scale development of } \\
\text { prefabricated rural residential buildings, } \\
\text { accounting for } 50 \% \text {. } \\
\text { 3. Green buildings account for } 50 \% \text { of } \\
\text { new rural residential buildings. }\end{array}$ & $\begin{array}{l}\text { Promote zero carbon rural } \\
\text { residential buildings and enhance } \\
\text { the application of distributed } \\
\text { energy in rural areas. }\end{array}$ \\
\hline \multirow{2}{*}{$\begin{array}{l}\text { Public } \\
\text { building }\end{array}$} & $\begin{array}{l}\text { Control } \\
\text { objectives }\end{array}$ & $\begin{array}{l}\text { 1. The total amount is controlled at } \\
15.2 \sim 17.9 \text { billion } \mathrm{m}^{2} \text {. } \\
\text { 2. The per capita area is between } 10 \text { and } 13 \\
\mathrm{~m}^{2} \text {. } \\
\text { 3. Rapid growth, with an average annual } \\
\text { increase of about } 0.55 \text { billion } \mathrm{m}^{2} \text {. }\end{array}$ & $\begin{array}{l}\text { 1. The total amount is controlled at } \\
18.3 \sim 19.7 \text { billion } \mathrm{m}^{2} \text {. } \\
\text { 2. The per capita area is between } 13 \\
\text { and } 14 \mathrm{~m}^{2} \text {. } \\
\text { 3. The average annual increase is about } \\
0.36 \text { billion } \mathrm{m}^{2} \text {. }\end{array}$ & $\begin{array}{l}\text { 1. The total amount is controlled at } \\
\text { 20 21 billion } \mathrm{m}^{2} \text {. } \\
\text { 2. The per capita area is between } 14 \text { and } \\
15 \mathrm{~m}^{2} \text {. } \\
\text { 3. slowly increase. The average annual } \\
\text { increase is about } 0.26 \text { billion } \mathrm{m}^{2} \text {. }\end{array}$ & $\begin{array}{l}\text { 1. The total amount is controlled at } \\
21.2 \sim 20.9 \text { billion } \mathrm{m}^{2} \text {. } \\
\text { 2. The per capita area is between } 15 \\
\text { and } 17 \mathrm{~m}^{2} \text {. } \\
\text { 3. There is a negative growth } \\
\text { gradually, from } 0.2 \text { billion } \mathrm{m}^{2} / \text { year } \\
\text { to }-0.1 \text { billion } \mathrm{m}^{2} / \text { year. }\end{array}$ \\
\hline & $\begin{array}{l}\text { Policy } \\
\text { measures }\end{array}$ & $\begin{array}{l}\text { 1. Improve the infrastructure of public } \\
\text { services and make resource allocation more } \\
\text { reasonable. } \\
\text { 2. Green buildings account for } 80 \% \text { of new } \\
\text { public buildings. } \\
\text { 3. Completed the reconstruction of } 200 \\
\text { million } \mathrm{m}^{2} \text { of existing public buildings. }\end{array}$ & $\begin{array}{l}\text { 1. The public service infrastructure is } \\
\text { more complete and the allocation of } \\
\text { resources is more reasonable. } \\
\text { 2. Green buildings account for } 100 \% \text { of } \\
\text { new public buildings. } \\
\text { 3. Completed the reconstruction of } 800 \\
\text { million } \mathrm{m}^{2} \text { of existing public buildings. }\end{array}$ & $\begin{array}{l}\text { Completed the reconstruction of } 1 \\
\text { billion } \mathrm{m}^{2} \text { of existing public buildings. }\end{array}$ & $\begin{array}{l}\text { Completed the reconstruction of } \\
5.5 \text { billion } \mathrm{m}^{2} \text { of existing public } \\
\text { buildings. }\end{array}$ \\
\hline
\end{tabular}




\section{Conclusions}

In this study, civil buildings are divided into residential buildings and public buildings, and the corresponding area calculation methods are extracted according to the characteristics of each type of buildings. By using the analysis of building-related indicators, three different development scenarios including benchmark, medium control, and strict control are constructed, and the development scale of various civil buildings in China from 2020 to 2060 is predicted. The main conclusions are as follows.

(1) Under the three scenarios, the total amount of civil buildings in China will reach peaks of $93.5,84.6$, and 76.3 billion $\mathrm{m}^{2}$ in 2040, 2035, and 2035, respectively. Under the constraints of energy consumption and carbon emission, this paper suggests that civil buildings develop according to the medium control scenario. In 2035, the urban per capita residential area will reach a peak of $42 \mathrm{~m}^{2}$, the urban residential area will reach 43 billion $\mathrm{m}^{2}$, the rural per capita residential area will reach the peak of $55 \mathrm{~m}^{2}$, the rural residential area will reach 20.6 billion $\mathrm{m}^{2}$, and the public building area will reach 21 billion $\mathrm{m}^{2}$. By 2060, the total area of civil buildings will drop to 76.5 billion $\mathrm{m}^{2}$, including 37.1 billion $\mathrm{m}^{2}$ of urban residential buildings, 18.5 billion $\mathrm{m}^{2}$ of rural residential buildings, and 20.9 billion $\mathrm{m}^{2}$ of public buildings.

(2) In order to achieve the total amount of control goals of civil buildings under the above medium control scenario, this paper proposes the phased control goal and implementation route of various buildings. Comprehensively considering the balance between people's demand for a better life and area control under the medium control scenario for the control increment of urban housing, it is necessary to complete the transformation of old communities in stages and to strive to realize new urbanization as soon as possible. For rural housing, reasonable planning for rural housing and improving the utilization rate of rural housing should be prioritized. For public buildings, improving public service infrastructure, setting phased transformation objectives, gradually increasing the proportion of green buildings, and gradually shifting the focus of construction from incremental construction to improving quality should be prioritized.

Due to resource and time constraints, this paper still needs to be improved. Firstly, the parameter values are mainly obtained by using literature research and calculation, and there is a lack of field research. Secondly, the economic development level of China's provinces is different. The calculation method in this paper is based on the national average, which should also be adjusted according to the actual situation of each province.

Author Contributions: Conceptualization, W.Z.; methodology, T.G.; validation, J.L., C.L. and K.M.; writing - original draft preparation, T.G.; T.G. and W.Z. contributed equally to this study. All authors have read and agreed to the published version of the manuscript.

Funding: This study was supported by the National Natural Science Foundation of China (Grant No. 51908287), National Natural Science Foundation of Jiangsu Province (Grant No. BK20180484), and China National Key R\&D Program (Project No. 2018YFC0704400).

Institutional Review Board Statement: Not applicable.

Informed Consent Statement: Not applicable.

Data Availability Statement: Not applicable.

Acknowledgments: This study was supported by the National Natural Science Foundation of China (Grant No. 51908287), National Natural Science Foundation of Jiangsu Province (Grant No. BK20180484), and China National Key R\&D Program (Project No. 2018YFC0704400).

Conflicts of Interest: The authors declare no conflict of interest. 


\section{References}

1. Xi, J. Speech at the general debate of the seventy-fifth United Nations General Assembly. People's Repub. China State Counc. Bull. 2020, 28, 5-7.

2. Research Institute of Standards and Norms Ministry of Housing and Urban-Rural Development. Control Strategy of Total Energy Consumption of Civil Buildings in China-Top-Level Design of Energy Conservation of Civil Buildings; Architecture \& Building Press: Beijing, China, 2016.

3. Kou, Y.; Hu, Y. Current situation and prediction of urban residential building area and energy consumption in hot summer and warm winter areas. Wall Mater. Innov. Build. Energy Conserv. 2016, 1, 63-66.

4. Wu, Y. China Building Energy Consumption Research Report; China Association of Building Energy Efficiency: Beijing, China, 2017.

5. Sartori, I.; Sandberg, N.H.; Brattebø, H. Dynamic building stock modelling: General algorithm and exemplification for Norway. Energy Build. 2016, 132, 13-25. [CrossRef]

6. Peng, C.; Jiang, Y. Road Map of Building Energy Conservation in China; China Architecture \& Building Press: Beijing, China, 2015.

7. Bürger, V.; Hesse, T.; Köhler, B.; Palzer, A.; Engelmann, P. German Energiewende-Different visions for a (nearly) climate neutral building sector in 2050. Energy Effic. 2019, 12, 73-87. [CrossRef]

8. Qi, F.; Musonda, B.M.; Shen, H.; Wang, Y. Geometric classification method of rural residences at regional scale. Energy Build. 2018, 172, 170-180. [CrossRef]

9. Müller, D.B. Stock dynamics for forecasting material flows-Case study for housing in The Netherlands. Ecol. Econ. 2016, 59, 142-156. [CrossRef]

10. Stephan, A.; Athanassiadis, A. Quantifying and mapping embodied environmental requirements of urban building stocks. Build. Environ. 2017, 114, 187-202. [CrossRef]

11. Li, X. Study on the Impact of Urbanization on Urban Building Carbon Emissions in China; Chongqing University: Chongqing, China, 2019.

12. Na, W.; Wang, H.; Hou, J.; Wu, Y. Analysis of public and industrial building area data of China based on Taylor-series neural network method (1). J. HVAC 2017, 47, 7-11.

13. Hou, J. Research on Energy Consumption Forecast and Energy Efficiency Improvement Roadmap of Urban Public Buildings in China; Beijing Jiaotong University: Beijing, China, 2017.

14. National Bureau of Statistics. China Statistical Yearbook 2013; Planning Press: Beijing, China, 2013.

15. Wang, M. Remarkable achievements have been made in the development of housing and urban and rural construction during the 13th Five Year Plan period. China Eng. Consult. 2020, 12, 16-18.

16. Energy Consumption Statistics Committee of China Building Energy Conservation Association. China Building Energy Consumption Research Report 2020; China Association of Building Energy Efficiency: Shanghai, China, 2020.

17. Building Energy Efficiency Research Center of Tsinghua University. Annual Development Research Report on Building Energy Efficiency in China 2020; China Architecture \& Building Press: Beijing, China, 2020.

18. Long, W. Thinking on building energy efficiency 2.0. J. HVAC 2016, 8, 1-12.

19. Chen, W. Index system and coordinated development evaluation of PRED system in Quanzhou. J. Quanzhou Norm. Univ. 2007, 2, 86-91.

20. Defeng, Z.; Zheng, Z.; Yu, Z. Comprehensive assessment of regional PRED system based on new urbanization approach: A case study in Dalian. Prog. Geogr. 2014, 33, 364-374.

21. Niu, X.; Du, Z.; Li, T. Evaluation of regional urbanization level based on new urbanization: A case of 10 provincial cities in Shaanxi Province. Arid. Land Geogr. 2013, 36, 354-363.

22. Wang, Y.; Wang, P. Temporal and spatial pattern and aggregation characteristics of county urbanization from the perspective of new urbanization-A case study of Zhejiang Province. Arid. Land Geogr. 2019, 42, 203-212.

23. Cai, J. Study on regional ecological efficiency from the perspective of new urbanization-Taking the panel data of 17 prefectures and cities in Shandong Province as an example. Resour. Sci. 2015, 37, 175-182.

24. Zhang, M.; Yu, S. Urbanization quality evaluation and regional difference analysis based on entropy method-A case study of Hunan Province. Heilongiiang Financ. 2018, 474, 67-70.

25. Xia, C. Housing indicators: A Perspective of international comparison. Shanghai Real Estate 2019, 3, 51-56.

26. Eurostat [EB/OL]. Available online: https:/ / ec.europa.eu/eurostat (accessed on 25 February 2021).

27. Ronald, B. Mitchell and the IEA Database Project. International Environmental Agreements (IEA) Database Project [DB/OL]. Available online: https:/ / www.iea.org/ (accessed on 25 February 2021).

28. Ministry of Land, Infrastructure, Transport and Tourism of Japan [EB/OL]. Available online: http://www.mlit.go.jp/ (accessed on 25 February 2021).

29. National Survey Research Center at Renmin University of China. Chinese General Social Survey (CGSS) [EB/OL]. Available online: http:/ / cgss.ruc.edu.cn/ (accessed on 25 February 2021).

30. Sun, W. Changes in the number of households and the housing demand of Chinese Residents. Soc. Sci. J. 2020, 6, 160-166.

31. National Health and Family Planning Commission. Report on the Family Development in China 2015; China Population Publishing House: Beijing, China, 2015.

32. Ministry of Education of the People's Republic of China [EB/OL]. Available online: http://www.moe.gov.cn/ (accessed on 8 November 2021). 
33. Ministry of Housing and Urban Rural Development. China Urban and Rural Construction Statistical Yearbook; China Architecture \& Building Press: Beijing, China, 2019.

34. China Economic Census [EB/OL]. Available online: http://www.stats.gov.cn/ztjc/zdtjgz/zgjjpc/d4cjjpc/ (accessed on 8 November 2021).

35. National Health Commission Planning Development and Information Technology Department. General Hospital Construction Standard (Draft for Comments) [EB/OL]. Available online: http:/ / www.nhc.gov.cn/guihuaxxs/s3585/201810/2d75433091104 2efa6c30fb63ec39578.shtml/ (accessed on 25 February 2021).

36. JB163-2013Construction Standards of Community Health Service Centers and Stations, China Planning Press: Beijing, China, 2013.

37. JB107-2008Construction Standard of Township Health Centers, China Planning Press: Beijing, China, 2008.

38. National Health Commission of the People's Republic of China. Basic Standards for Medical Institutions (Trial) [EB/OL]. Available online: http:/ / www.nhc.gov.cn/ (accessed on 25 February 2021).

39. JB189-2017Construction Standard of Maternal and Child Health Service Institutions, China Planning Press: Beijing, China, 2017.

40. JB169-2014Construction Standard for Office Space of Party and Government Organs, China Planning Press: Beijing, China, 2014.

41. JB191-2018Building Area Index of Colleges and Universities, China Planning Press: Beijing, China, 2018.

42. State Education Commission. Planned Area Quota of School Buildings for Full-Time Ordinary Secondary Vocational Schools (for Trial Implementation) [EB/OL]. Available online: http://old.mohurd.gov.cn/fgjs/xgbwgz/200902/t20090211_185704.html/ (accessed on 25 February 2021).

43. JB102-2002Ministry of Education of the People's Republic of China. Standard for School Building Construction of Urban Ordinary Primary and Secondary Schools, China Planning Press: Beijing, China, 2002.

44. JB109-2008Construction Standard of Rural Ordinary Primary and Secondary Schools, China Planning Press: Beijing, China, 2008.

45. JB156-2011Construction Standards of Special Education Schools, China Planning Press: Beijing, China, 2011.

46. JB175-2016Kindergarten Construction Standard, China Planning Press: Beijing, China, 2016.

47. JGJ 66-2015Code for Design of Museum Building, China Architecture \& Building Press: Beijing, China, 2015.

48. JB136-2010Construction Standard of Cultural Center, China Planning Press: Beijing, China, 2010.

49. JB160-2012Construction Standard of Township Comprehensive Cultural Station, China Planning Press: Beijing, China, 2012.

50. JGJ/T60-2012Code for Design of Passenger Transportation Building, China Architecture \& Building Press: Beijing, China, 2012.

51. JGJ86-92China Institute of Building Standard Design \& Research Co., Ltd. Code for Architectural Design of Port Passenger Station, China Architecture \& Building Press: Beijing, China, 1992.

52. TB 10099-2017Code for Design of Railway Station and Terminal, China Railway Publishing House: Beijing, China, 2017.

53. MH5002-1999Code for Master Planning of Civil Airport, Civil Aviation Administration of China: Beijing, China, 2000.

54. Jones Lang LaSalle. Beijing plans to expand the stock of office buildings. City House 2013, 8, 62-63.

55. Lu, F. Beijing office market is weak. China Real Estate Mark. 2013, 8, 46-47.

56. Zhang, J. Analysis and Forecast of Factors Influencing Hangzhou Office Building Demand; Zhejiang Sci-Tech University: Hangzhou, China, 2012.

57. Ministry of Commerce of the People's Republic of China. Construction Standard of Agricultural and Sideline Products Wholesale Market (For Internal Printing Only) [EB/OL]. Available online: http:/ / www.chinacoop.gov.cn/ news.html?aid=839937/ (accessed on 25 February 2021).

58. Wang, Y.; Wei, Q.; Xue, Z.; Jiang, Y. Energy saving consultation of large public buildings (III)—Investigation and Analysis on energy consumption of large public buildings. Constr. Sci. Technol. 2007, 2, 17-19.

59. Ministry of Housing and Urban-Rural Development. China Urban Construction Statistical Yearbook; China Architecture \& Building Press: Beijing, China, 2006.

60. Lu, J. The Era of Negative Population Growth: Characteristics, Risks and Strategies. J. Soc. Dev. 2019, 6, 21-32.

61. Zhang, X.; Zhai, Z.; Tao, T. Trends and Patterns of Negative Population Growth in China. Popul. Res. 2020, 44, 3-20.

62. The CPC Central Committee and the State Council. National new urbanization planning (2014-2020). Rural. Work. Commun. 2014, 6, 32-48.

63. Dai, Y.; Zhu, Y.; Bai, Q. China's road to low carbon development in 2050-Scenario analysis of energy demand and carbon emission. Rev. Econ. Res. 2010, 26, 2-22.

64. Pan, Y.; Liang, Y.; Zhu, M. Review of building carbon emission calculation models in context of carbon neutrality. J. HVAC 2021, 51, 37-48.

65. Zhao, H. Enlightenment from the development of British health service system to the development of Chinese medical architectures. Chin. Hosp. Archit. Equip. 2017, 18, 41-47.

66. Nickl-Weller, C.; Nickl, H. Development and prospect of medical buildings in Germany. Chin. Hosp. Archit. Equip. 2017, 18, 25-27.

67. The CPC Central Committee and the State Council issued 2035 of China's educational modernization. People's Daily, 24 February 2019.

68. Bian, R. Analysis of Supply and Demand Status and Demand Forecast of Office Market in Changchun City; Changchun Institute of Technology: Changchun, China, 2019.

69. Zhu, X. Research on the development trend of hotel industry. Technol. Econ. Guide 2019, 27, 199-200.

70. Yu, G.; Zhao, J. Characteristics and trends of China's catering industry in the new era. J. Commer. Econ. $2019,3,167-171$. 